A new finding of the European mudminnow (Umbra krameri, Walbaum 1792) in Croatia

Novi nalaz crnke (Umbra krameri Walbaum 1792) u Hrvatskoj

Jelkić, D., Opačak, A., Ozimec, S., Blažetić, S., Lužaić, R., Vukajlović, N.

Poljoprivreda/Agriculture

ISSN: 1848-8080 (Online)

ISSN: 1330-7142 (Print)

http://dx.doi.org/10.18047/poljo.25.1.9

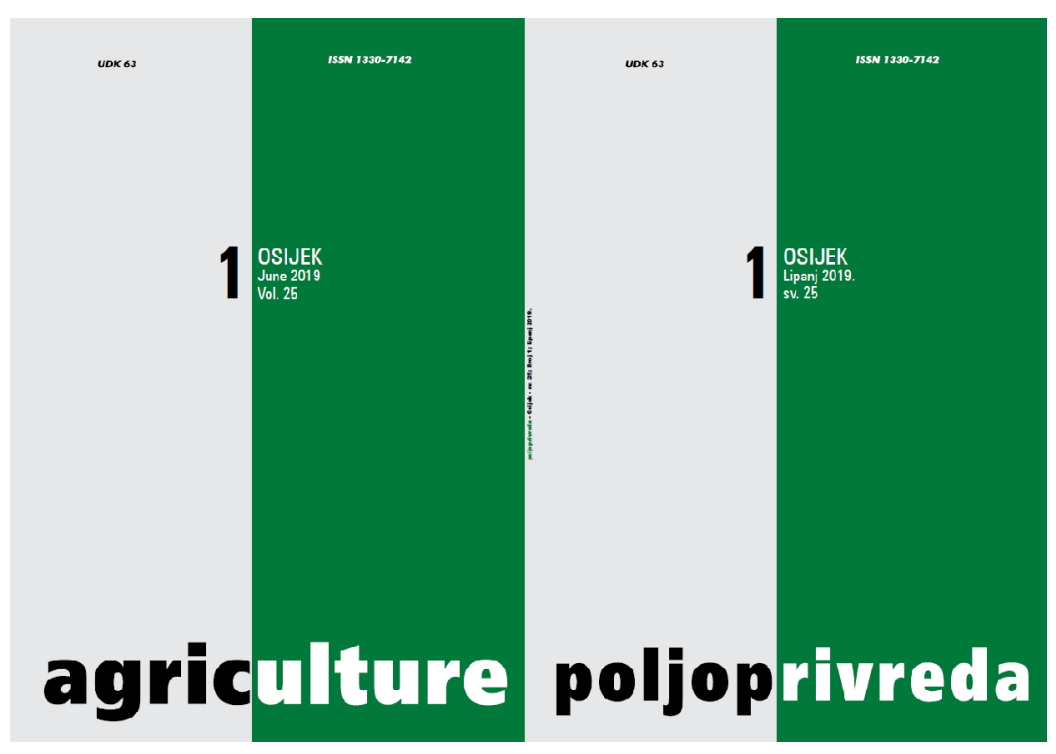

Fakultet agrobiotehničkih znanosti Osijek, Poljoprivredni institut Osijek

Faculty of Agrobiotechnical Sciences Osijek, Agricultural Institute Osijek 
ISSN $1330-7142$

$U D K=639.2 .053 .2(497.5)$

DOI: $10.18047 /$ poljo.25.1.9

\title{
A NEW FINDING OF THE EUROPEAN MUDMINNOW (Umbra krameri, Walbaum 1792) IN CROATIA
}

Jelkić, D.(1), Opačak, A. (1), Ozimec, S.(1), Blažetić, S. ${ }^{(2)}$, Lužaić, R. ${ }^{(1)}$, Vukajlović, N.(1)

Original scientific paper

Izvorni znanstveni članak

\begin{abstract}
SUMMARY
Distribution of the European mudminnow, Umbra krameri, Walbaum 1792, in Croatia is scarce with only few confirmed localities. In order to confirm presence of the European mudminnow in amelioration canal network along the Drava River an electrofishing was conducted in the small Mlinski canal. Ten specimen of European mudminnow were caught During sampling. Using ImageJ software a truss network was constructed between landmark points on photographs of caught specimens. Total body lengths of caught European mudminnow ranged from 61 to $100 \mathrm{~mm}$ $(72.00 \pm 11.52 \mathrm{~mm})$ whereas standard one ranged from 52 to $85 \mathrm{~mm}(60.30 \pm 10.08$ $\mathrm{mm})$. Body weight were relatively small ranging from 1.81 to $7.59 \mathrm{~g}(3.80 \pm 1.89 \mathrm{~g})$, while the Fulton condition factor ranged from 0.76 to $1.23(0.96 \pm 0.15)$. This new locality of the European mudminnow is situated about $50 \mathrm{~km}$ downstream from the last confirmed site in Croatia.
\end{abstract}

Key words: Umbridae, Croatia, distribution, truss network

\section{INTRODUCTION}

Destruction of natural habitats and introduction of non-native, exotic or alien fish species, both led to the changes in fishes biodiversity in Croatia and other European countries. The freshwater ichthyofauna of Croatia comprise 150 fish species (Mrakovčić et al., 2006). One of endangered endemic freshwater fish with minimal knowledge about the population distribution in Croatia is the European mudminnow (Umbra krameri, Walbaum, 1792). The European mudminnow is an endemic stagnophile species of the Danube and Dniester River drainages (Hajdú et al., 2015). It was the most abundant fish species in many parts of the Danube in the last thirty years (Kovac, 1997). In general, the areas where the species can be found are mainly marsh land and swamp regions (Wanzenböck, 1995; Freyhof, 2012) or small streams with densely overgrown parts, ditches and ponds (Wilhelm, 2003; Pekárik et al., 2014). However, due to agriculture development, river management and stream regulations the population of European mudminnow has undergone a mayor decrease (Pekárik et al., 2014). Hajdú et al. (2015) states that European mudminnow population has declined by more than $30 \%$ in the past ten years. European mudminnow has no commercial, angling or nutritional value for local inhabitants (Leiner, 1995). Because of that, there is a lack of information about its distribution and population dynamics in Croatia. Leiner (1995) gives the actual localities with registered specimens of European mudminnow in Croatia (Lonja, Zelina and Mura River) and suggests likely localities along the Drava River. Delić et al. (1997) confirms stable population of European mudminnow in the amelioration canal network near settlements Starogradački Marof and Virovitica and hypotheses that this species spent their live almost entirely in amelioration canal network along the Drava River. Aiming to confirm this hypothesis, sampling of ichthyofauna was conducted in the vicinity of the village Vaška, where a network of amelioration canals has a periodically connection with two sidearms of the Drava River and a floodplain.

(1) Assist. Prof. Dinko Jelkić, Ph.D. (djelkic@fazos.hr), Prof. Anđelko Opačak, Ph.D., Assoc. Prof. Siniša Ozimec, Ph.D., Ras Lužaić, M. Eng. Agr., Nevena Vukajlović, M. Eng. Agr. - Josip Juraj Strossmayer University of Osijek, Faculty of Agrobiotechnical Sciences Osijek, Vladimira Preloga 1 , 31000 Osijek, Croatia, (2) Senka Blažetić, Ph.D. - Josip Juraj Strossmayer University of Osijek, Department of Biology, Ulica cara Hadrijana 8/A, 31000 Osijek, Croatia 


\section{MATERIAL AND METHODS}

Electrofishing was conducted at single location in May 2013 in a small amelioration canal, named Mlinski canal (Figure 1) in the proximity of the Drava River and Vaška village. A selected site was representative habitat type of nearby network of amelioration canals and floodplain of the Drava River. A sampling site was 100 $\mathrm{m}$ long, with average width of three meters. Fishes were sampled using 350 V DC generator (EL65II model), and upstream twin method with stop-nets. The captured fishes were counted, placed in oxygenated tanks and returned in wild after analyses procedure. European mudminnows were placed on the right side and photographed along a measuring tape, followed by total length $(T L)$, standard length (SL), body width $(B H)$ and body weight (BW) measurements (Table 1). Since the European mudminnow is strictly protected, photos were taken and all the following measurements were con- ducted using ImageJ software (Ferreira and Rasband, 2012). A truss network was constructed between landmark points (Figure 2), according to Strauss and Bookstein (1982). The following measurements were taken (MTFH) mouth top to forehead end of frontal bone, (FHPC) forehead to pectoral fin, (PMPC) premaxilla to pectoral fin, (MTPM) mouth tip to premaxilla, (MTPC) mouth top to pectoral fin, (PMFH) premaxilla to forehead, (FHDF) forehead to dorsal fin, (DFPF) dorsal fin to pelvic fin, (PCPV) pectoral fin to pelvic fin, (FHPV) forehead to pelvic fin, (DFPC) dorsal fin front to pectoral fin, (DFDB) dorsal fin front to dorsal fin back, (DBAF) dorsal fin back to anal fin, (PVAF) pelvic fin to anal fin, (DFAF) dorsal fin to anal fin, (DBPV) dorsal fin back to pelvic fin, (DBCT) dorsal fin back to caudal top, (CTCB) caudal top to caudal bottom, (AFCB) anal fin to caudal bottom, (DBCB) dorsal fin back to caudal bottom, (AFCT) anal fin to caudal top.

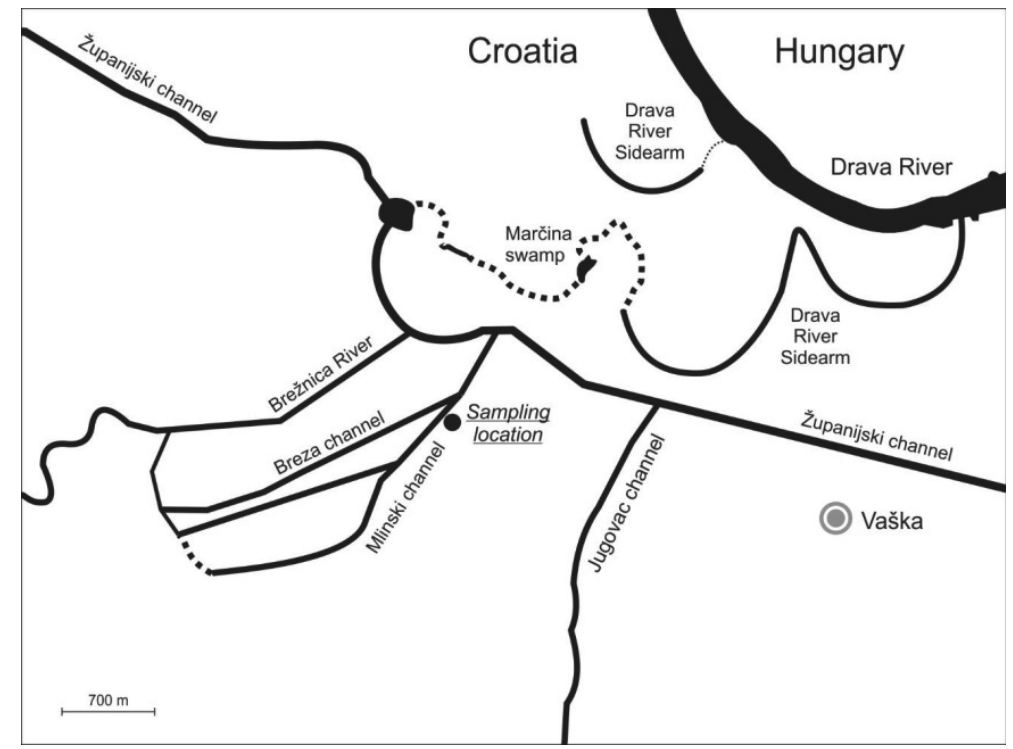

Figure 1. Sampling location in Croatia near the Drava River.

Slika 1. Mjesto uzorkovanja u blizini rijeke Drave u Hrvatskoj.

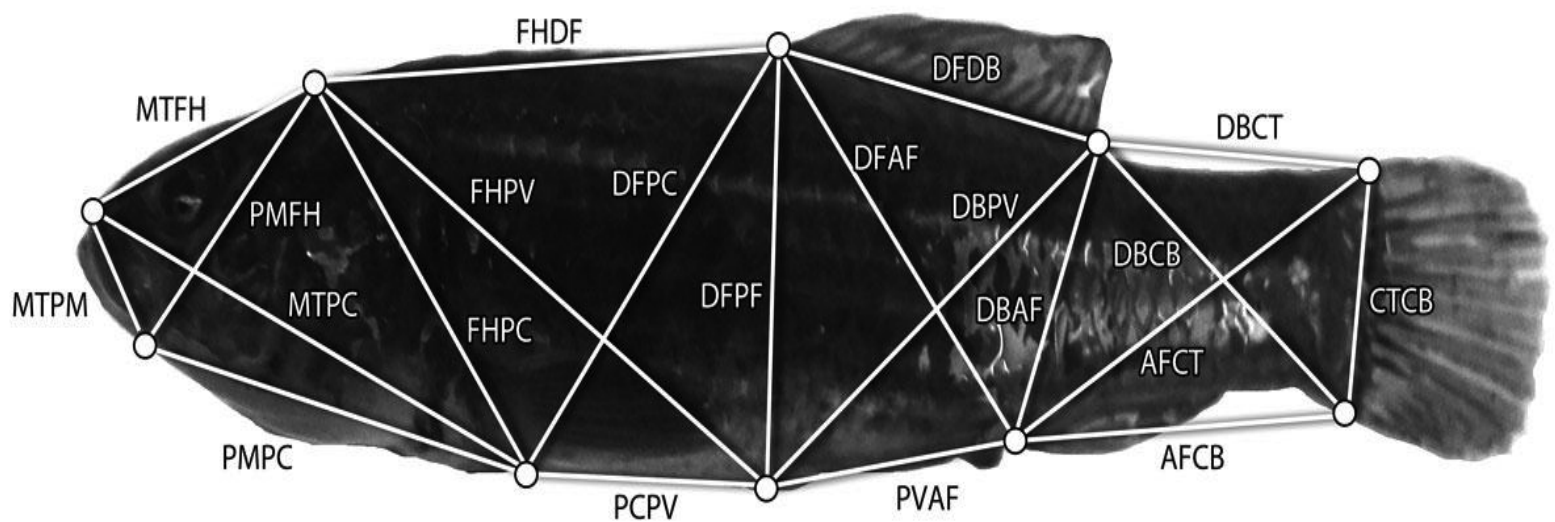

Figure 2. Truss network landmarks on European mudminnow.

Slika 2. Slika crnke s oznakama metode razgranate mreže. 


\section{RESULTS AND DISCUSSION}

During sampling, 10 specimens of European mudminnow were caught. The morphometric data of captured European mudminnow are presented in Table 1. Total body length of caught European mudminnows ranged from 61 to $100 \mathrm{~mm}(72.00 \pm 11.52 \mathrm{~mm})$ and standard length ranged from 52 to $85 \mathrm{~mm}(60.30 \pm 10.08$ $\mathrm{mm})$. Body weight were relatively small and ranging 1.81 to $7.59 \mathrm{~g}(3.80 \pm 1.89 \mathrm{~g})$, while the Fulton condi- tion factor ranged from 0.76 to $1.23(0.96 \pm 0.15)$. The gender of caught European mudminnows couldn't be visually distinguish, because spawning period is between March and April. During the sampling, other fish species were recorded: roach (Rutilus rutilus), bleak (Alburnus alburnus), spirlin (Alburnoides bipunctatus), european bitterling (Rhodeus amarus), danubian spined loach (Cobitis elongatoides), weather loach (Misgurnus fossilis) and invasive prussian carp (Carassius gibelio).

Table 1. Morphometric data of the captured European mudminnows.

Tablica 1. Morfometrijski podatci ulovljenih primjeraka ribe crnke.

\begin{tabular}{|c|c|c|c|c|c|c|c|c|c|c|}
\hline \multirow{2}{*}{$\begin{array}{l}\text { Abbreviation } \\
\text { Pokrata }\end{array}$} & \multicolumn{10}{|c|}{ Specimen number - Redni broj primjerka } \\
\hline & 1 & 2 & 3 & 4 & 5 & 6 & 7 & 8 & 9 & 10 \\
\hline BW (g) & 7.59 & 6.32 & 4.49 & 2.22 & 3.66 & 2.69 & 2.71 & 2.37 & 1.81 & 4.09 \\
\hline FC & 0.76 & 1.23 & 1.06 & 0.85 & 1.11 & 0.94 & 0.99 & 0.86 & 0.8 & 0.97 \\
\hline TL (mm) & 100.0 & 80.00 & 75.00 & 64.00 & 69.00 & 66.00 & 65.00 & 65.00 & 61.00 & 75.00 \\
\hline $\mathrm{SL}(\mathrm{mm})$ & 85.00 & 67.00 & 63.00 & 53.00 & 57.00 & 56.00 & 53.00 & 54.00 & 52.00 & 63.00 \\
\hline $\mathrm{BH}(\mathrm{mm})$ & 18.00 & 18.00 & 18.00 & 16.00 & 17.00 & 16.00 & 15.00 & 8.00 & 9.00 & 16.00 \\
\hline MTFH (mm) & 22.19 & 17.60 & 13.23 & 14.47 & 10.74 & 13.37 & 13.07 & 13.21 & 10.99 & 13.95 \\
\hline FHPC (mm) & 17.50 & 17.74 & 15.95 & 11.88 & 12.30 & 12.72 & 12.50 & 12.05 & 11.02 & 14.52 \\
\hline PMPC (mm) & 18.02 & 16.38 & 16.19 & 14.24 & 13.23 & 14.39 & 13.52 & 13.30 & 11.55 & 15.20 \\
\hline MTPM (mm) & 8.16 & 9.42 & 6.59 & 4.16 & 6.16 & 6.19 & 6.10 & 5.45 & 5.62 & 5.20 \\
\hline MTPC (mm) & 25.85 & 24.72 & 21.57 & 18.00 & 17.71 & 19.35 & 18.85 & 17.72 & 16.97 & 20.08 \\
\hline PMFH (mm) & 19.25 & 16.80 & 13.15 & 13.73 & 11.57 & 12.92 & 12.33 & 12.72 & 9.35 & 13.79 \\
\hline FHDF (mm) & 23.75 & 18.05 & 18.68 & 13.19 & 15.55 & 14.95 & 14.13 & 13.99 & 14.38 & 17.96 \\
\hline DFPF (mm) & 16.92 & 17.92 & 15.83 & 13.10 & 13.33 & 13.88 & 12.04 & 11.15 & 11.82 & 15.18 \\
\hline PCPV (mm) & 18.90 & 15.64 & 13.28 & 11.53 & 12.86 & 11.71 & 11.26 & 10.91 & 10.36 & 14.15 \\
\hline FHPV (mm) & 29.00 & 26.80 & 25.62 & 18.97 & 20.68 & 20.40 & 19.81 & 19.07 & 19.61 & 24.44 \\
\hline DFPC (mm) & 25.35 & 22.19 & 18.39 & 15.59 & 17.57 & 16.89 & 14.78 & 14.60 & 13.79 & 18.43 \\
\hline DFDB (mm) & 20.48 & 16.74 & 15.59 & 11.57 & 13.41 & 12.31 & 12.17 & 13.09 & 12.41 & 15.36 \\
\hline DBAF (mm) & 14.83 & 13.15 & 11.65 & 10.01 & 11.08 & 10.31 & 9.75 & 9.23 & 8.95 & 11.36 \\
\hline PVAF (mm) & 8.92 & 8.90 & 7.46 & 7.28 & 6.99 & 7.62 & 6.50 & 5.69 & 6.05 & 8.92 \\
\hline DFAF (mm) & 19.56 & 19.40 & 18.73 & 14.93 & 14.88 & 15.77 & 14.11 & 13.28 & 14.01 & 17.71 \\
\hline DBPV (mm) & 21.82 & 19.89 & 16.04 & 14.17 & 15.94 & 15.10 & 13.92 & 13.40 & 13.19 & 17.63 \\
\hline DBCT (mm) & 13.32 & 12.65 & 12.57 & 10.48 & 11.83 & 11.94 & 10.27 & 9.54 & 8.74 & 11.98 \\
\hline СTCB (mm) & 10.92 & 10.05 & 9.11 & 7.20 & 8.67 & 7.68 & 7.83 & 7.02 & 7.78 & 8.33 \\
\hline $\mathrm{AFCB}(\mathrm{mm})$ & 22.88 & 17.25 & 14.22 & 12.74 & 14.02 & 14.46 & 13.36 & 13.76 & 13.19 & 17.37 \\
\hline $\mathrm{DBCB}(\mathrm{mm})$ & 16.68 & 15.69 & 14.16 & 12.85 & 12.54 & 13.25 & 11.99 & 11.48 & 12.30 & 15.00 \\
\hline AFCT (mm) & 25.72 & 21.45 & 19.13 & 15.98 & 19.44 & 18.44 & 16.90 & 16.38 & 14.96 & 19.98 \\
\hline
\end{tabular}

The average body mass of European mudminnows was $3.80 \pm 1.89 \mathrm{~g}$, which corresponds to values reported by Wilhelm (2003) for European mudminnow in the River Ér (Hungary) with similar length groups. Delić et al. (1997) didn't report on body mass of caught specimens but only total length in range from 41 to 119 $\mathrm{mm}$. The Europen mudminnows caught in Mlinski canal had similar length classes. Generally, Fulton condition factor for caught European mudminnow was low in comparison to other freshwater fishes in the Drava River. Similar results of Fulton condition factor for the European mudminnow was reported by Sekulić (2013) on three different locations where Fulton condition factor was between 0.91 to 1.17. Spearman correlation between total body length and Fulton's condition factor indicates positive correlation $\left(r_{s}=0.849, N=9, p<0.01\right)$ 
in the caught specimens. Sekulić (2013) also stated that Fulton's condition factor for European mudminnow positively correlates with total body length in the caught male specimens while it negatively correlates in females, where Fulton's condition factor decreases. Interestingly, specimen number 1 , having the maximum total body length $(100 \mathrm{~mm})$ also had the smallest value for Fulton condition factor (0.76).

\section{CONCLUSION}

Based on the research by Delić et al. (1997) and Leiner (1995), we can conclude that European mudminnow has fragmented population in amelioration channels and floodplain of the Drava River. The European mudminnow in Croatia was not confirmed downstream of 165 river kilometre of the Drava River and this new locality in the vicinity of the village Vaška is about $50 \mathrm{~km}$ downstream from the last confirmed site. It seems that European mudminnow has adapted to live in amelioration canals since the original habitat, marsh land and swamp areas, are gradually reducing and disappearing. Ameliorations canals network is densely overgrown with macrophyte vegetation, with extremely slow current and standing parts, providing shelter and food source for the European mudminnow. Also, the absence of predators, during electrofishing have a positive impact on the sustainability of the population of European mudminnow. At this time there is no conservation or restocking plan for the European mudminnow in Croatia. Maintaining the population of the European mudminnow in Croatia by artificial reproduction is a possibility, based on research under laboratory conditions (Kovac, 1997). Also, the technology of recirculation aquatic systems (RAS) had significant progress and by combining the artificial reproduction and the RAS it is reasonably possible to grow the month old fry's, as in the example for the common carp, Cyprinus carpio (Jelkić et al., 2014).

\section{REFERENCES}

1. Delić, A., Razlog-Grlica, J., \& Grlica, I. D. (1997). Nova nalazišta crnke (Umbra krameri Walbaum 1972) u Hrvatskoj. Ribarstvo, 55(3), 93-98.

2. Ferreira, T., \& Rasband, W. (2012). ImageJ user guide. Retrieved from https://imagej.nih.gov/ij/docs/guide/ user-guide.pdf
3. Freyhof, J. (2012). Threatened freshwater fishes and molluscs of the Balkan, potential impact of hydropower projects. Unpublished report, ECA Watch Austria\&EuroNatur.

4. Hajdú, J., Várkonyi, L., Ševc, J., \& Müller, T. (2015) Corrective notice to the European mudminnow (Umbra krameri Walbaum, 1792) record from the Black Sea. Biologia, 70(10), 1429-1431. https://doi.org/10.1515/biology-2015-0157

5. Jelkić, D., Opačak, A., Horvat, D., \& Safner, R. (2014). Common carp fry survival during salinity stress test: effect of feeding regime-short communication. Veterinarski arhiv, 84(4), 429-438.

6. Kovac, V. (1997). Experience with captive breeding of the European mudminnow, Umbra krameri Walbaum, and why it may be in danger of extinction. Aquarium Sciences and Conservation, 1(1), 45-51. https://doi.org/10.1023/A:1018323315109

7. Leiner, S. (1995). The status of the European mudminnow, Umbra krameri Walbaum, 1792, in Croatia (Pisces: Umbridae). Annalen des Naturhistorischen Museums in Wien. Serie B für Botanik und Zoologie, 486-490.

8. Mrakovčić, M., Brigić, A., Buj, I., Ćaleta, M., Mustafić, P., \& Zanella, D. (2006). Red book of freshwater fish of Croatia. Ministry of Culture. State Institute for Nature Protection, Republic of Croatia, 253.

9. Pekárik, L., Hajdú, J., \& Košo, J. (2014). Identifying the key habitat characteristics of threatened European mudminnow (Umbra krameri, Walbaum 1792). Fundamental and Applied Limnology/Archiv für Hydrobiologie, 184(2), 151-159. https://doi.org/10.1127/1863-9135/2014/0477

10. Sekulić, N. K. (2013). Ekološke karakteristike morfološko-genetička diferencijacija populacija crnke (Umbra krameri Walbaum, 1792) sa područja Bačke, Mačve i Semberije (Doctoral dissertation, University of Beograd, Faculty of Biology).

11. Strauss, R. E., \& Bookstein, F. L. (1982). The truss: body form reconstructions in morphometrics. Systematic Biology, 31(2), 113-135. https://doi.org/10.2307/2413032

12. Wanzenböck, J. (1995). Current knowledge on the European mudminnow, Umbra krameri Walbaum, 1792 (Pisces: Umbridae). Annalen des Naturhistorischen Museums in Wien. Serie B für Botanik und Zoologie, 439-449.

13. Wilhelm, A. (2003). Growth of the mudminnow (Umbra krameri Walbaum) in river Ér. Tiscia, 34, 57-60. 


\section{NOVI NALAZ CRNKE (Umbra krameri Walbaum 1792) U HRVATSKOJ}

\section{SAŽETAK}

Informacije o distribuciji crnke, Umbra krameri Walbaum 1792, u Hrvatskoj su oskudne, uključujući svega nekoliko potvrđenih lokaliteta. U svrhu potvrđivanja prisutnosti crnke u mreži melioracijskih kanala u blizini rijeke Drave, obavljeno je uzorkovanje ribe elektroagregatom na Mlinskome kanalu. Tijekom uzorkovanja ulovljeno je 10 primjeraka crnke. Korištenjem računalnoga programa ImageJ razvijena je metoda razgranate mreže na fotografijama

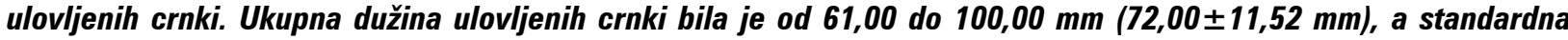
dužina iznosila je od $52,00 \mathrm{do} 85,00 \mathrm{~mm}(60,30 \pm 10,08 \mathrm{~mm})$. Ukupna tjelesna masa bila je relativno mala, u rasponu

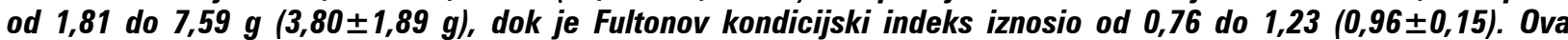
nalazište crnke u Hrvatskoj smješteno je oko 50 km nizvodno od zadnjega potvrđenog lokaliteta uz tok rijeke Drave.

Ključne riječi: Umbridae, Hrvatska, distribucija, metoda razgranate mreže

(Received on September 10, 2018; accepted on March 29, 2019 - Primljeno 10. rujna 2018.; prihvaćeno 29. ožujka 2019.) 